\title{
'User' links strengthened in NERC shake-up
}

London. Britain's Natural Environment Research Council (NERC) has decided to eliminate the three senior positions in its current management structure responsible for running separate science-based directorates, and to replace them with a single director for science and technology.

The move is designed to improve both the management efficiency of the NERC and its responsiveness to the needs of its 'user' communities. But it has also highlighted ambiguity over whether, following last year's white paper (government policy document) on science, the research council is itself an independent 'contractor' of research, or a 'customer' acting on behalf of government and industry.

The three positions to disappear will be

\section{Wellcome Trust warns of research 'in peril'}

London. The director of the Wellcome Trust, Britain's largest medical research charity, which last year awarded research grants totalling almost $£ 150$ million (US $\$ 225$ million), has warned that government reforms of the National Health Service (NHS) are placing the future of clinical research in the United Kingdom "undoubtedly in peril".

The warning comes in the latest annual report of the trust, which has recently been forced to reconsider its investment in new laboratory facilities at Hammersmith Hospital in London following the government's refusal to cover the costs of protecting research investments in a merger with the nearby Charing Cross Hospital (see Nature 369, 92; 1994).

Bridget Ogilvie, the director of Wellcome, says that the implementation of a "purchaser/ provider' split - with hospital managers seeking to provide services at the lowest possible price - is having "serious consequences" for clinical research. In particular, she writes, the changes are making "enormous demands" on senior medical staff with responsibility for both clinical training and research.

She also says that the trust is watching "with concern" how changes in the funding of research, following the publication of last year's white paper, are being put into practice - and in particular the consequences of the new remit of the research councils to respond to the needs of users of research.

Ogilvie points out that senior government officials have recently condemned efforts by others to subject key members of the community to the Maoist philosophy of continuous revolution. "It is greatly to be hoped that this comment will be implemented by those with responsibility for the university sector, and also the NHS," she writes. the directorate heads for marine and atmospheric sciences, for Earth sciences and for terrestrial and freshwater sciences. Each of these currently has line responsibility for overseeing a range of NERC laboratories and research institutes.

The occupant of the new post will be responsible for the implementation of NERC's scientific strategy for the whole environment. To complement this, the institutes will be formed into two groupings, each intended to enhance their roles as 'contractors' to the council.

Each centre will have its own director, who will be responsible for the professional management and organization of the component institutes (although the directors will be at a lower civil service grade than the previous directorate heads - and the new science and technology director).

One grouping will be a new Centre for Coastal and Marine Sciences, which will include for example both the Plymouth and Dunstaffnage Marine Laboratories. The second is a Centre for Ecology and Hydrology, grouping four separate institutes working in terrestrial and freshwater areas.

The move is partly designed to level the playing field for research groups competing for grants in the Earth, marine and environmental sciences, placing scientists working inside and outside the council on a more equal footing when it comes to applying for research funding.

But it is also intended to pick up on the theme of the white paper by increasing the potential influence of the 'users' of NERC research in deciding which fields should receive priority funding. Indeed, an important part of the new director's responsibility will be to develop NERC's role as a 'customer' for the research that it pays for in both universities and its own institutes.

A senior scientist will be appointed to

take responsibility for what is described as 'technology interaction', and the new director for science and technology will be required to balance the scientific priorities of the academic community with the views of potential users expressed, for example, by the results of the government's technology foresight exercise.

"This is quite a radical change for the NERC," says John Krebs, professor of zoology at the University of Oxford, who took over the new position of chief executive officer of the NERC last month. He says that the reorganization is an attempt to move away from the previous situation which had tended to lock the NERC into committing funds to its institutes rather than universities. "Buying the best science where you can get it is something that all the research councils are moving towards," he says.

The reorganization has been actively encouraged by the Office of Science and Technology which, in line with the government's wish to stimulate a more marketoriented approach to the management of publicly funded research, is keen to see a greater separation between the roles of customers and contractors within the research councils.

But it has also opened up the question of how far the customer/contractor relationship, which in its original formulation by Lord Rothschild was intended to apply to links between research councils and government departments, can legitimately be applied to the workings of the research councils themselves.

Of particular concern to some scientists is the extent to which the council will consider that it still has a long-term responsibility for the scientific health of its individual institutes. "This is certainly an issue which has yet to be resolved," said one observer last week.

David Dickson

\section{$\$ 60$ million gift for neurobiology research}

Cambridge, Massachusetts. The Harvard Medical School plans to use the investment income from a $\$ 60$-million gift the largest it has ever received - to conduct neurobiological research aimed at resolving some of the mysteries surrounding cerebral palsy.

The research will concentrate on how nerve cells develop, how they adapt to external stimuli, and how they die, emphasizing the way in which these activities affect and are affected by the condition of cerebral palsy. The donation has been made by Isabelle and Leonard Goldenson in recognition of the support given by scientists at the medical school in the 1950 s to their daughter, who suffered from cerebral palsy.
Mr Goldenson is the founder of the American Broadcasting Companies, Inc. and chairman of the executive committee of Capital Cities/ABC, Inc. The school plans to dedicate a newly renovated research building to the Goldensons in September. Although no money from the gift will be used for the renovation, the donation will finance research to be conducted in the new laboratories.

In 1953, the late Sidney Farber of Harvard helped Mrs Goldenson to found the United Cerebral Palsy Research and Education Foundation. This combined the efforts of US medical schools, and members of both medical and technology departments, to help scientists to learn more about cerebral palsy. Victoria Griffith 